\title{
HRANIČNÉ ŽIVOTNÉ SITUÁCIE A ICH STVÁRNENIE V PRÓZE PRE DETI A MLÁDEŽ
}

\section{Extreme Life Situations and their Depiction in the Prose for Children and Youth}

Keywords: children prose, youth prose, environmental problems, ecological problems

Contact: Univerzita Pavla Jozefa Šafárikav Košiciach; gabriela.eibenova@student.upjs.sk

\section{Interpretácia diela Lišiak Pax}

Dielo americkej autorky Sary Pennypackerovej Lišiak Pax $^{1}$ patrí medzi diela, ktoré detskému percipientovi citlivo a nenásilne približujú viacero eticko-ekologických otázok a problémov. Zároveň je to príbeh vzácneho priatel’stva a pevnej citovej väzby medzi malým chlapcom Petrom a jeho lišiakom, ktorého nazýva Pax.

Už prostredníctvom kompozičných postupov vo vstupnej časti diela, incipitu ${ }^{2}$ a introdukcie ${ }^{3}$, je naznačený hlboký vzt'ah chlapca a lišiaka, ktorý v podstate otvára príbeh a tvorí prvú kapitolu diela. V incipite: „Lišiak postrehol, že auto spomal’uje, skôr ako chlapec.“ (Pennypackerová 2017: 11) sa percipient zoznamuje s dvomi ústrednými postavami diela, a to chlapcom a lišiakom.

Príbeh sa začína cestou chlapca a lišiaka v aute. Rozprávanie môžeme označit' ako chronologické, pričom je doplnené niekol'kými retrospektívnymi odbočeniami. Dielo je v podstate postavené na dôvere a výnimočne blízkom vzt'ahu medzi Petrom a Paxom. Ich vzt’ah zároveň posilňuje emocionálnu stránku diela a citový zážitok, ktorý príbeh ponúka detskému percipientovi. Vel'mi emotívne pôsobí úvodná scéna, ked' je chlapec donútený nechat' lišiaka $\mathrm{v}$ lese. Táto scéna otvára dej príbehu, možno ju považovat' za akýsi odrazový mostík, od ktorého sa odvíjajú aj d’alšie dôležité udalosti.

Po odlúčení Petra a Paxa sa Peter dostáva k starému otcovi. Postupne sa dozvedáme o dôvodoch, pre ktoré bol Peter nútený opustit' Paxa, ale aj svoj domov:

\footnotetext{
${ }^{1}$ Ikar, a.s., 2017, prel. Michal Jedinák.

2 „Incipit (z lat. incipere = začínat') je sémanticky zat'ažená vstupná veta textu, ktorá dáva kl'úč alebo aspoň čiastočný kl’úč k nasledujúcemu dianiu.“(Všetička 1986: 49).

3 „Introdukcia je vstupná situácia v texte, je to prvopočiatok diela a začiatok expozície.“ (Všetička 1986: 50).
} 
„Blíži sa vojna. Každý prinesie nejakú obet'. Ja musím nastúpit' do služby - je to moja povinnost'. A ty musíš odíst'““(Pennypackerová 2017: 19). Petrov život teda začínajú ovplyvňovat' spoločenské udalosti - vojna, ktorá síce nepriamo, ale výrazne narušila jeho komfort a istotu, na ktorú bol zvyknutý.

Neskôr sa dozvedáme aj o d’alších dôležitých udalostiach a momentoch, ktoré značne ovplyvnili Petrovo detstvo. Po príchode k starému otcovi sa protagonista v spomienkach vracia do minulosti. Zážitky s Paxom striedajú spomienky na Petrovu mamu. Jej smrt' je percipientovi sprostredkovaná len implicitne, dotvára však celkový obraz o živote a situácii hlavného hrdinu. Percipient tak postupne dostáva odpovede na otázky, ktoré sa vynárajú počas čítania. Retrospektívny obraz Petrovho života je podaný vel'mi zaujímavo a originálne. Ako sme už spomenuli, veselé zážitky s Paxom striedajú bolestivé spomienky na mamu, čo môže miestami pôsobit' mierne chaoticky. Na druhej strane však vd’aka tomuto spôsobu rozprávania príbeh v tejto časti pôsobí dynamickejšie a môžeme ho považovat' za akýsi obraz situácie, ktorá sa odohráva v Petrovej hlave. Zároveň je náznakom neistoty a zmätku $\mathrm{v}$ jeho živote a obrazom okolností, $\mathrm{s}$ ktorými nie je zmierený.

Pri retrospektívnom pohl'ade do minulosti si Peter vybaví nepríjemný zážitok ako v pasci našiel mítveho zajaca, ktorého zrejme na smrt' vystrašili kojoty. Tento zážitok v protagonistovi vyvolá negatívne pocity, kladie si za vinu, že zviera nezachránil. Práve tieto spomienky sú pre hlavného hrdinu podnetom a silnou motiváciou k nájdeniu Paxa. Zbalí si najnutnejšie veci, rozhodne sa opustit' dom starého otca a vydat' sa na riskantnú a na prvý pohl'ad takmer neuskutočnitel'nú cestu s ciel’om nájst' svojho lišiaka.

Za vel'mi originálny považujeme autorkin spôsob práce s napätím. V niekol'kých častiach diela je prítomný motív tajomstva. Tento premyslený kompozičný postup dodáva dielu dynamiku, príbeh vd’aka nemu pôsobí prítažlivejšie, ale hlavne napínavejšie. V priebehu deja sú postupne odkryté mnohé odpovede na otázky o Petrovej minulosti, nie sú však vypovedané priamo. Tvoria súčast' spomienok protagonistu a postupne dopíňajú predstavu o jeho minulosti a jej následkoch na súčasné konanie a citové rozpoloženie.

Príbeh je tvorený dvomi dejovými líniami, pričom jedna sprostredkúva osud chlapca a druhá osud lišiaka. Tieto dejové línie sú po formálnej stránke rozlíšené pravidelne sa striedajúcimi kapitolami - jedna sa venuje Petrovi a jeho neutíchajúcej túžbe nájst' svojho priatel'a zo zvieracej ríše, druhú dejovú líniu tvorí príbeh lišiaka, ktorý sa snaží prežit' bez svojho pána v prostredí, ktoré je mu v podstate cudzie. Čo sa týka rozprávača, môžeme tu hovorit’ o personálnom rozprávačovi, ktorý sa sústredí striedavo na Paxa a na Petra. 
Život lišiaka Paxa po tom, ako ho hlavný hrdina spolu otcom vypustil v lese, možno charakterizovat' ako ustavičný boj o prežitie. V tomto prípade by sme mohli hovorit' o istom rozpore. Pax sa síce ocitá v lese, prostredí, ktoré je preňho ako pre šelmu prirodzené, adaptácia na novú situáciu a prostredie však preňho predstavuje značný problém: „Pax bol hladný, uzimený a zobudil sa na to, že potrebuje prikrývku.“ (Pennypackerová 2017: 30). Tomuto faktu sa rozprávač venuje podrobnejšie. Pax sa $\mathrm{v}$ lese dostáva do blízkosti líšky, ktorá je v príbehu nazývaná Ježatá, a jej brata, malého lišiaka, či starého lišiaka menom Sivý a jeho družky. Môžeme tak sledovat' rozdiel medzi životom líšok zvyknutých na ich prirodzené prostredie a teritórium a lišiaka, ktorý sa snaží prežit'v doteraz neznámom prostredí a učí sa od skúsenejších rovnakého druhu. Pax pôsobí medzi ostatnými líškami vel'mi placho, nesmelo a osamotene. Tento fakt je umocnený nepriatel'ským a spočiatku vel'mi odmeraným prístupom Ježatej, ktorá len s vel'kou nevôlou vpúšt’a neznámeho na svoje územie. ${ }^{4}$ Autorka tak premyslene prepája fiktívny príbeh s reálnym životom a správaním zvierat. Líšky skutočne patria k zvieratám, ktoré si poctivo strážia svoje teritórium. ${ }^{5}$ Čitatel'sky atraktívne pôsobí spôsob dorozumievania medzi líškami, ktorý má v príbehu dôležité miesto. Líšky medzi sebou komunikujú rečou, ktorá je po formálnej stránke odlíšená kurzívou. Prehovory zvieracích postáv sú odkazom na ničenie ich prirodzeného prostredia l’ud’mi. Načrtáva sa nám tu teda aktuálna a pomerne vážna téma ochrany životného prostredia. Príbeh detskému percipientovi nenásilným spôsobom ukazuje súčasné environmentálne problémy, ktoré sú v tomto prípade zobrazené cez prizmu zvierat. Nejde tu teda o explicitný výklad a explicitné vymenovanie problémov, ktoré v súčasnosti trápia našu biosféru, čo je, vzhl'adom na vek potencionálneho percipienta, vel'mi vhodne zvolený spôsob. Na druhej strane je však dôležité poznamenat', že spôsob, akým sú tieto problémy det'om približené, je vel'mi ohl'aduplný vzhl'adom k nevinnému detskému svetu, nenásilný, ale za to vel'mi originálny a presvedčivý.

Vel'kú hrozbou pre líšky, ktoré v príbehu vystupujú, prestavuje vojna. Vojna sa v príbehu kladie do vel'mi úzkej súvislosti s l’ud’mi, ktorí sú z pohl'adu zvierat chápaní negatívne. Cítia z nich strach a nebezpečenstvo, čo súvisí s nepríjemnými zážitkami a spomienkami: „Ešte vždy sú bezohl'adní? Boli takí, ked’ som s nimi žil.“ (Pennypackerová 2017: 63). Vojna je v diele vysvetlená cez prizmu zvierat: „Existuje choroba, ktorou sa občas nakazia lišky. Vtedy sa správajú inak a útočia na cudzích. Vojna je zas l'udská choroba.“ (Pennypackerová 2017: 63). Chápanie vojny ako l’udskej choroby svojím spôsobom ospravedlňuje konanie tých, ktorí sú za vojnu zodpovední.

\footnotetext{
${ }^{4}$ „Každá líška má vyhradené svoje lovecké územie, ktoré si bráni pred inými líškami. Pravidelne ho obchádza a značkuje trusom alebo močom. Tým dáva signál iným líškam, že územie je už obsadené.“ (Čačko, L. Osamelý lovec. Dostupné na: https://www.quark.sk/osamely-lovec/ (2021-02-24)).

${ }^{5}$ Informácie dostupné na: https://ekolist.cz/cz/publicistika/priroda/liska-obecna-skryte-zijici-lovec (2021-02-24).
} 
Ďalšou postavou, ktorá v príbehu vystupuje, je postava samotárky Voly, ktorú Peter stretáva na ceste za Paxom po tom, ako si nešt’astnou náhodou zlomí nohu. Vola pôsobí pomerne odmeraným dojmom. Táto postava je dokonalým príkladom preživšej vojny, ktorú jej následky, fyzické, ale aj psychické, nezvratným spôsobom ovplyvnili v konaní, správaní, ale aj myslení. Vola sama priznáva, že trpela posttraumatickou stresovou poruchou. Zabudla, aký život žila pred vojnou, čo ju naplńalo a robilo št’astnou. Zvrátený a bezcitný charakter vojny autorka zvýrazňuje aj porovnaním Voly ako nevinného diet’at’a a neskôr človeka, ktorý bol schopný zabit'. Trpí výčitkami svedomia, nedokáže si odpustit' smrt' vojaka, ktorú zavinila. Ako spomienka na mítveho vojaka a strašný čin, ktorý spáchala, jej ostáva knižka s názvom Sedem ciest Sindibáda námorníka, ktorú si vojak vzal so sebou na front. Do hry tu teda v podobe odkazu na iné dielo vstupuje intertextualita.

Príbeh sa uzatvára stretnutím Petra a Paxa. Možno tu hovorit' o otvorenom konci. Petrovi sa síce podarí dosiahnut' svoj ciel', nájst' Paxa, pochopí však, že odteraz už lišiak patrí do lesa, svojho prirodzeného prostredia, medzi ostatné líšky a zvieratá: „Peter pochopil. Jeho lišiak patrí im. A oni patria Paxovi. Sú nerozluční.“ (Pennypackerová 2017: 243). V diele môžeme pozorovat' prerod Paxa z nesmelého lišst'at'a, ktoré sa ocitlo v neznámom prostredí, na statočného a odvážneho lišiaka. Stará sa o Ježatú a raneného Drobca, ktorý prišiel o nohu pri výbuchu, je svedkom smrti lišiaka Starého, ktorého privalil strom. Tieto udalosti sú zároveň asociáciou na častú sebeckost' a ignorantstvo l'udstva a absurdnost' vojny.

\section{Interpretácia diela Vlčie oko}

Novela Vlčie oko $^{6}$, dielo jedného z najprekladanejších francúzskych autorov Daniela Pennaca, autora niekol'kých diel pre detského, ale aj dospelého čitatel'a ${ }^{7}$, je síce primárne určené pre detského percipienta, svojím poučným príbehom si však určite nájde miesto aj v literatúre pre dospelých.

Čo sa týka kompozičnej výstavby, dielo pozostáva zo štyroch kapitol. V prvej kapitole s názvom Stretnutie sa percipient zoznamuje s dvomi ústrednými postavami diela, chlapcom a vlkom. Ich tajomné stretnutie otvára príbeh a uvádza čitatel’a do deja. Incipit diela: „Pred vlčou klietkou nehybne stál chlapec.“ (Pennac 2016: 9) vel’mi výstižne naznačuje situáciu a bariéru, ktorá je medzi vlkom a chlapcom. Klietka, v ktorej sa nachádza vlk sledujúci chlapca ako sa naňho trpezlivo pozerá. Táto situácia je zároveň zobrazená aj graficky, na obrázku. Medzi chlapcom a vlkom sa nachádza

\footnotetext{
${ }^{6}$ NM CODE \& Asociácia Corpus, 2016, prel. Beata Panáková.

${ }^{7}$ Informácie dostupné na: https://www.walker.co.uk/contributors/Daniel-Pennac-5717.aspx (2021-02-24). 
biela čiara symbolizujúca klietku, a teda bariéru, ktorá ich oddel’uje. Vizuálna stránka však $\mathrm{v}$ tomto prípade úplne nekorešponduje s verbálnou, ked’že na ilustrácii stoja chlapec a vlk vo vol'nej prírode obklopení otvoreným priestranstvom, ktoré môžeme chápat' ako symbol slobody a vol’nosti. Vizuálna stránka teda predstavuje obraz slobody a nezávislosti, kým verbálna stránka je odrazom väznenia a obmedzovania pohybu, ktorý je pre vlka prirodzený.

Koniec prvej kapitoly symbolizuje zblíženie a spriatelenie sa chlapca a vlka: „Vlkovi však niečo prekáža. Je to hlúpe. Má len jedno oko a chlapec má dve oči.“ (...) Vtedy chlapec urobí niečo zvláštne. Čosi, čo vlka upokojí a uistí. Chlapec zavrie jedno oko.“ (Pennac 2016: 15). V tejto časti sa teda dozvedáme o hendikepe vlka, ktorý má len jedno oko. Za znak a symbol istého spojenectva a priatel'stva medzi chlapcom a vlkom možno považovat' práve to, že chlapec jedno oko zatvára. Je to empatický prejav diet'at'a voči zvierat'u.

Čo sa týka rozprávača, v tomto prípade môžeme hovorit' o vševediacom rozprávačovi. Kompozícia, ktorú autor volí, pôsobí vel’mi originálne. Máme tu dočinenia s príbehom, ktorý je v podstate vsadený do d’alšieho príbehu. Pri pohl'ade chlapca do vlčieho oka sa nám otvára d'alší príbeh - príbeh vlka pred jeho zajatím v ZOO. Zrenička oka predstavuje vlčicu skrútenú do klbka a dúhovka okolo zreničky sedem víčat, okolo ktorých vlčica leží. Tento príbeh symbolicky začína v momente, ked' chlapec jedno oko zatvára. Tento akt naznačuje vcit'ovanie, vžívanie sa do príbehu uväzneného zvierat’a.

Práve tu sa začína rozvíjat' rozprávanie o rodine Modrého vlka - vlka zo zoologickej záhrady. Autor tu vel'mi zaujímavo pracuje s motivovanost'ou mien vlčej rodiny. Možno tu hovorit' o tzv. nomen omen, ked’že vlastné mená niektorých vlkov sú motivované ich najtypickejšími vonkajšími znameniami. Srst' Modrého vlka je sfarbená do modra, Čierna iskra, matka víčat, je jednak sfarbená do čierna, táto farba je však zároveň alúziou na čiernu zreničku Modrého vlka: „Najvýraznejšia je však zrenička. Čierna zrenička!“‘ (Pennac 2016: 17). Rovnako sa zoznamujeme aj s Čačkou, víčat’om so zlatou kožušinou, sestrou Modrého vlka. Jej meno možno chápat’ ako alúziu na zlatú farbu, resp. ozdôbku, pričom zlatú farbu môžeme považovat' za farbu niečoho hodnotného či cenného. Čačka je tiež považovaná za najkrajšiu vlčicu s vel'mi dobre vyvinutými zmyslami.

Rodina Modrého vlka reprezentuje zvieratá a ich život, ktorý je neustále ohrozovaný l'ud'mi. Človek predstavuje pre zviera hrozbu, je stelesnením strachu: „Nie, ja chcem počut' o l'ud’och, ozajstný strašidelný príbeh.“ (Pennac 2016: 20). Vlci musia neustále utekat' pred pol'ovníkmi túžiacimi po vlčej kožušine, a tak žijú v ustavičnom 
strachu a napätí. Ich život, vol'nost' a sloboda, ktorá je pre zvieratá prirodzená a nevyhnutná, l'udia neustále ohrozujú. Táto skutočnost' vrcholí scénou, v ktorej je Čačka uväznená v sieti v pol'ovníckom tábore. Pol'ovníci Čačku chytili, vd'aka Modrému vlkovi sa jej však podarí vyslobodit'. Jeho obetavost' Čačku zachránila, on sa však dostáva do zajatia, do zoologickej záhrady. Práve po záchrane Čačky ostáva jedno oko vlka zatvorené.

Tretiu kapitolu s názvom L’udské oko tvorí príbeh chlapca zo ZOO. Rovnako ako vlk ukazoval svoje spomienky chlapcovi, ukazuje teraz chlapec svoje spomienky Modrému vlkovi: „A teraz sa premieňa chlapcovo oko. Ako vyhasnuté svetlo.“ (Pennac 2016: 43). Chlapca a vlka spája podobný životný príbeh. Obaja sú nútení odíst' zo svojho prirodzeného prostredia d'aleko od svojich blízkych. Chlapec zrejme v dôsledku vojny prichádza o svoju matku. Strata životnej istoty a bezpečného prostredia je v diele vyjadrená neustálymi zmenami, ktorými chlapec prechádza. L’udia v jeho blízkosti sa menia, prichádzajú a odchádzajú, a nedokážu chlapcovi poskytnút' oporu, ktorú potrebuje. Jedinou istotou a priatel'mi chlapca sú zvieratá, ktoré sa dostávajú do jeho blízkosti. Najprv je to Hrkálka, t’ava sebeckého obchodníka Tou, s ktorým chlapec strávi istý čas, neskôr je to gepard, ktorého stretáva pri práci u Kozieho král'a. Práve tu sa ukazuje chlapcovo bystré, dôvtipné a vel'mi múdre uvažovanie.

Vel'mi dôležitou súčast'ou života malého chlapca sú príbehy „o Žltej Afrike, o Sahare, o piesočnej krajine, o slnku, o samote, o škorpiónoch, o tichu.“ (Pennac 2016: 49), ktoré l'ud'om rozpráva. Ked’že chlapec je pre všetkých l'udí vôkol seba neznámy a nikto, ani on sám, nepozná jeho skutočné meno, dostáva meno podl'a príbehov o Afrike: „Toa, budeme tohto chlapca volat' Afrika.“ (Pennac 2016: 50). Rozprávaním a svojimi vedomost’ami chlapec pripomína múdreho a rozvážneho starca, ktorého rady majú skutočný význam a zmysel. Ani Toa, ani Kozí král' však nedokážu, ale predovšetkým nechcú dat' chlapcovi to, čo naozaj potrebuje - lásku a skutočný domov. Ten nachádza až u Papu a Mamy Biovcov, ku ktorým sa dostáva po autonehode: „A tak sa z neho stal Afrika N’Bia, najmladšie diet’a Papu a Mamy Biovcov.“ (Pennac 2016: 67). V tomto bode do deja vstupuje otázka ochrany životného prostredia a environmentálnych problémov. Neohl'aduplné zásahy človeka do prirodzeného prostredia zvierat, vyrúbané lesy či vel'ké sucho, nútia opustit' rodinu N'Bia svoj domov a odíst' do tzv. Inakšieho sveta. Autor tak detskému percipientovi opät' vel'mi jemne a nenútene vysvetl'uje problémy, ktoré trápia súčasný svet a ekológiu. Spôsob rozprávania, ktorý autor volí, pôsobí poučne, zároveň však vel'mi emotívne a dojímavo. Rovnako tu je naznačený problém migrácie $\mathrm{z}$ environmentálnych dôvodov.

Posledná kapitola diela s názvom Inakší svet je v podstate vysvetlením otázok, ktoré si počas čítania čitatel' kladie. Papa Bia sa zamestnáva v mestskej zoologickej 
záhrade, práve v tej, v ktorej sa Afrika zoznamuje s Modrým vlkom. Práve tu opät' stretáva stratené zvieratá - t’avu Hrkálku, Hyenu, Geparda či kozl'atá Kozieho krála. Táto skutočnost' pôsobí optimistickým dojmom štastného konca, zároveň však v sebe skrýva vel'mi silný odkaz s poučným charakterom. Kontrast slobody, vol’nej prírody a neobmedzeného pohybu s múrmi zoologickej záhrady je jasnou alúziou na utrpenie zvierat, ktorému sú vystavené. Detský percipient vd’aka vel'mi citlivo a pokojne podanému problému dokáže vnímat' a pochopit' alegoricky zakódované posolstvo $\mathrm{v}$ diele, ktoré vyznieva emotívne, nie však prehnane sentimentálne.

Záverečná kapitola diela je opät' venovaná vzt’ahu chlapca a Modrého vlka a ich vzácnemu putu. V podstate tu možno hovorit' o istom zarámovaní príbehu ${ }^{8}$. Prvá a posledná kapitola sa odohrávajú $\mathrm{v}$ rovnakom priestore - v zoologickej záhrade, pričom záverečná kapitola je akoby pokračovaním prvej. V súvislosti s týmito dvoma rámcujúcimi kapitolami je dôležité spomenút, že obe sa vpodstate odohrávajú v súčasnosti, zatial' čo pri ostatných kapitolách ide o retrospektívne rozprávanie chlapca a vlka. Ako sme spomenuli na začiatku, chlapec pri pohl'ade na vlka zatvára jedno oko, pričom následne mu vlk akoby dovolí vidiet' jeho životný príbeh. Na konci rozprávania má chlapec oko stále zatvorené. Každé ráno, už celé mesiace, otvára len jedno oko, čo si jeho noví rodičia, a dokonca ani lekár, nedokážu vysvetlit'. Nikto okrem Modrého vlka netuší, že zatvorené oko nesúvisí so žiadnou chorobou. V úplnom finále príbehu chlapec oko otvorí, ale až po tom, ako ho otvorí vlk. Chlapec tak svojím spôsobom donúti vlka otvorit' oko a presvedčí ho, že aj v zoologickej záhrade, mimo svojho prirodzeného prostredia má zmysel pozerat' sa na svet okolo seba oboma očami. Otvorené oči možno zároveň považovat' za akýsi symbol zahojenia starých rán, nový začiatok a pohlad vpred, do budúcna.

\section{Zhrnutie}

Obe analyzované diela sú určené pre detského, resp. adolescentného percipienta a zaoberajú sa pomerne vážnymi a aktuálnymi ekologicko-etickými témami a problémami. Predovšetkým je to problém ohrozenia životného prostredia, narúšanie prírodných biotopov človekom či zásahy človeka do prirodzeného prostredia živočíchov, ale aj vojna, hlavne v diele Lišiak Pax. Všetky tieto témy sú síce náročné a ich spracovanie si vyžaduje vel'mi opatrný a citlivý prístup vzhl'adom na ich adresnost', považujeme však za dôležité, aby sa s nimi postupne oboznamoval aj detský

\footnotetext{
8 „Zarámovanie je v podstate založené na paralelnom princípe, na paralelizmoch medzi začiatkom a koncom literárneho diela.“(Všetička 1986: 55).
} 
percipient. Zároveň však musíme podotknút, že tieto témy sú v oboch interpretovaných dielach spracované naozaj vel'mi jemne a taktne s ohl'adom na citlivý detský svet.

Čo sa týka protagonistov oboch príbehov, aj v diele Lišiak Pax, aj v diele Vlčie oko sa protagonisti nachádzajú mimo svojho bezpečného domáceho prostredia. Aj Peter, aj Afrika sú v podstate siroty. Obaja prichádzajú o svoju životnú istotu, pocit bezpečia a ochranu svojich rodičov. Môžeme teda konštatovat', že sa nachádzajú v hraničnej životnej situácii mimo svojho domova a svojich blízkych. To isté platí aj pri zvieracích protagonistoch oboch diel. Lišiak aj vlk sú nútení opustit' prostredie, na ktoré sú zvyknutí, je medzi nimi však zásadný rozdiel. Lišiak Pax sa síce dostáva do lesa, prirodzeného prostredia líšok, ked’že však nikdy nežil vo vol'nej prírode, predstavuje preňho značný problém prispôsobit' sa životu vo vol’nej krajine medzi ostatnými zvieratami. Postupne si však zvyká a finále príbehu je dôkazom, že zviera ako líška naozaj patrí do vol'nej prírody. Domovom Modrého vlka je Aljaška, vol’ný pohyb a sloboda preňho teda predstavujú nevyhnutnú a prirodzenú súčast’ života, čo ostro kontrastuje s výrazne obmedzeným pohybom v zoologickej záhrade. Môžeme konštatovat', že práve prostredníctvom zoologickej záhrady autor poukazuje na bezohl'adnost' človeka, ktorý často ignoruje právo zvierat na ich slobodu a vol'ný pohyb.

Ďalším spoločným znakom diel, ktorý súvisí so zásahom do prirodzeného prostredia zvierat, ale aj l’udí, je vojna. V diele Lišiak Pax hrá vojna pomerne dôležitú úlohu, pričom v diele Vlčie oko je spomenutá len vel'mi nepriamo. Vojna zásadným spôsobom zasahuje do života Petra, protagonistu diela Lišiak Pax. Ani v tomto diele však nemožno o vojne hovorit' ako o leitmotíve príbehu. Vojna v diele nie je zobrazená priamo (nejde o konkrétny vojnový konflikt naviazaný na konkrétny priestor), je potrebné chápat' ju v širšom kontexte, ako súčast' globálnych problémov sveta, ktoré majú nezvratné následky jednak na prírodu, prírodné biotopy, ale aj l’udské osudy. Aj vd’aka takejto koncepcii sa autorovi podarilo ešte viac zdôraznit' dôsledky, hrôzostrašné javy, ktoré s vojnou súvisia, jej dopad na bežného človeka, deti, osudy l'udí, zvierat a prírody.

V diele Vlčie oko možno v súvislosti s vojnou hovorit' o akejsi kulise, ktorá je tiež súčast'ou väčšieho problému. Aj tu sa poukazuje predovšetkým na jej následky.

Zaujímavo zobrazené sú zároveň aj vzt’ahy medzi postavami. Medzil’udské vzt’ahy a vzt'ahy v rodine tvoria pomerne dôležitú súčast' diela Lišiak Pax. Komplikovaný vzt’ah s otcom, ktorý uprednostní odchod na front pred svojím synom, či nie práve vrúcny vzt'ah so starým otcom, sú v diele príkladom narušených rodinných väzieb. Tieto zložité vzt’ahy s dospelými si Peter kompenzuje svojím neobyčajne 
blízkym vzt'ahom s lišiakom, ktorý preňho predstavuje jedinú istotu. Do popredia tu teda vystupuje vzt'ah človeka a zvierat'a, na ktorom je v podstate dielo vybudované.

O podobnej situácii môžeme hovorit' aj v diele Vlčie oko. Tu máme opät' dočinenia so vzt'ahom človeka a zvierat'a. Chlapec si svojím blízkym spojením so zvieratami tiež v podstate kompenzuje absenciu dospelých vo svojom živote, nahrádzajú mu blízkost' a starostlivost' rodičov. Výnimočný je predovšetkým jeho vzt'ah s Modrým vlkom. Spojenie, ktoré medzi nimi vzniká, im obom pomáha zabudnút' na útrapy minulosti a vnímat' krásy, ktoré život ponúka. Vzt’ah človek - zviera je však v týchto dvoch spomínaných dielach zobrazený odlišne. V diele Vlčie oko by sme mohli hovorit' o istom tajomnom, magickom a rozprávkovom stvárnení tohto vzt'ahu, kdežto v diele Lišiak Pax puto medzi lišiakom a Paxom pôsobí reálnejšie, aj ked' má v sebe tiež istý náznak rozprávkovosti. V súvislosti s dielom Vlčie oko môžeme celkovo hovorit' o magickejšom vyznení diela. $V$ tomto diele sú použité fantastické a rozprávkové prvky, a to predovšetkým v súvislosti s okom vlka a chlapca, prostredníctvom ktorého je ich príbeh vyrozprávaný.

\section{Summary}

Our work describes extreme life situations and their depictions in prose for children and youth. We will focus on extreme life situations like war, death, loss of the close person, isolation and also environmental and ecological problems. On the basis of the interpretation of proses from American writer Sara Pennypacker Pax and French writer Daniel Pennac The Eye of the Wolf we will show, what kind of serious topics and motives can appear in the literature for children and youth and also how the world of people and the world of animals intertwine in these stories.

\section{Literatúra}

Dorul'a, J. et al. Krátky slovník slovenského jazyka. Bratislava: Veda, 2013.

Pennac, D. Vlčie oko. Bratislava: NM CODE \& Asociácia Corpus, 2016.

Pennypackerová, S. Lišiak Pax. Bratislava: Ikar, a. s. - Stonožka, 2017.

Všetička, F. Kompoziciána: o kompozičnej výstavbe prozaického diela. Bratislava: Slovenský spisovatel', 1986. 


\section{Internetové zdroje}

Čačko, L. Osamelý lovec. Dostupné na: https://www.quark.sk/osamely-lovec/ (202102-24).

Danniel Pennac. Dostupné na: https://www.databazeknih.cz/zivotopis/daniel-pennac1598 (2021-02-24).

Danniel Pennac. Dostupné na: https://www.walker.co.uk/contributors/Daniel-Pennac5717.aspx (2021-02-24).

Liška obecná - skrytě žijicí lovec. Dostupné na: https://ekolist.cz/cz/publicistika/ priroda/liska-obecna-skryte-zijici-lovec (2021-02-24).

(c) $(\$)$ The article is accessible in open access mode under licence CC BY-NC-ND BY NC ND

Creative Commons Attribution-NonCommercial-NoDerivatives 4.0 